\begin{tabular}{c} 
JURNAI R RS'II \\
IAll $\begin{array}{c}\text { (Rekayasa Sistem dan Teknologi Informasi) } \\
\text { Vol. 3 No.1 (2019) } 23-28\end{array}$ \\
\hline
\end{tabular}

\title{
Pengaruh Variabel Kualitas Sistem Informasi Terhadap Kepuasan Pengguna Sistem Informasi Model EUCS
}

\author{
Erick Sorongan $^{1}$, Hilmansyah $^{2}$, Hadiyanto ${ }^{3}$ \\ ${ }^{1,2,3}$ Jurusan Teknik Elektro, Prodi Teknik Elektronika, Politeknik Negeri Balikpapan \\ 1 erick.sorongan@poltekba.ac.id, ${ }^{2}$ hilmansyah@poltekba.ac.id, ${ }^{3}$ hadiyanto@poltekba.ac.id
}

\begin{abstract}
The application of information systems with various types of convenience offered can reflect the quality of service of an organization, the quality of service can be said to be very good if the service meets the needs and expectations of users. This kind of evaluation can be done by applying a tested model but problems arise when latent variables in the method used are not fully able to identify factors that influence user satisfaction. From the results of research using the end user satisfaction model, the R-Square value is 0.653 , which means that $65.3 \%$ of user satisfaction can be found through latent variables found in the EUCS model while the remaining $34.7 \%$ can be explained through external variables. This study aims to analyze external factors outside the EUCS model, one of which is by using the information system quality variables contained in the Delone and Mclane information system success model. The way to do this is to add an external variable to the EUCS model and then analyze the outer model and analyze the structural model using the structural equation model. The results showed that the independent system quality variable has a t-statistic value of 3.445 or greater than t-table 1.96 which means that the external latent variables of the Delone and Mclean model can be used to explain the satisfaction factors (from the external variable side) of the user information system on the EUCS model.
\end{abstract}

Keywords: quality system, end user satisfaction, information system

\begin{abstract}
Abstrak
Penerapan sistem informasi dengan berbagai macam kemudahan yang ditawarkan dapat mencerminkan kualitas pelayanan sebuah organisasi, kualitas pelayanan dapat dikatakan sangat baik apabila pelayanan tersebut memenuhi kebutuhan dan harapan pengguna. Evaluasi semacam ini bisa dilakukan dengan menerapkan sebuah model yang telah teruji akan tetapi muncul permasalahan ketika variabel laten pada metode yang digunakan tidak sepenuhnya mampu mengidentifikasi faktor-faktor yang mempengaruhi kepuasan pengguna. Dari hasil penelitian dengan menggunakan model end user satisfaction didapatkan nilai $R$-Square sebesar 0,653 yang artinya $65,3 \%$ kepuasan pengguna dapat diketahui melalui variabel laten yang terdapat pada model EUCS sedangkan sisanya $34,7 \%$ bisa dijelaskan melalui variabel eksternal. Penelitian ini bertujuan untuk menganalisis faktor eksternal diluar model EUCS, salah satunya dengan menggunakan variabel kualitas sistem informasi yang terdapat dalam model kesuksesan sistem informasi Delone and Mclane. Cara yang dilakukan adalah dengan menambahkan satu variabel eksternal kedalam model EUCS untuk selanjutnya dilakukan analisa outer model dan analisa model struktural menggunakan metode structural equation model. Hasil penelitian menunjukkan bahwa variabel independen kualitas sistem memiliki nilai $t$-statistic sebesar 3,445 atau lebih besar dari t-table 1,96 yang berarti variabel laten eksternal dari model Delone and Mclean dapat digunakan untuk menjelaskan faktor-faktor kepuasan (dari sisi variabel eksternal) pengguna sistem informasi pada model EUCS.
\end{abstract}

Kata kunci: kualitas sistem, kepuasan pengguna akhir, sistem informasi. 


\section{Pendahuluan}

Sistem informasi memiliki nilai strategis dan berperan sangat penting sebagai daya saing, kompetensi utama dan dalam keberlangsungan hidup dari suatu organisasi atau perusahaan. Tujuan utamanya adalah menghasilkan informasi untuk meningkatkan efisiensi, efektivitas, komunikasi, kolaborasi dan kompetitif[1]. Kepuasan pengguna akhir terhadap sistem informasi memberi pengaruh yang besar dalam perkembangan teknologi informasi. Chin dan Lee mendefinisikan bahwa kepuasan pengguna akhir dengan sistem
informasi dapat menjadi evaluasi yang efektif secara keseluruhan yang berhubungan dengan pengalaman pengguna sistem tersebut[2]. Sebuah penelitian dilakukan untuk menemukan faktor-faktor yang mempengaruhi ekspetasi pengguna layanan e-Health dengan menghubungkan dampak langsung kepada model user satisfaction, dimana hasilnya menunjukkan $39 \%$ ekspetasi berasal dari variabel lain diluar model yang dapat dijadikan panduan awal untuk mengembangkan layanan e-Health[3]. Hal tersebut menunjukkan bahwa variabel eksogen diluar model penelitian yang digunakan memiliki pengaruh dalam keberhasilan suatu sistem informasi. Sehingga menjadi salah satu alasan utama pentingnya dilakukan sebuah penelitian yang mampu menemukan variabel eksternal yang memiliki pengaruh signifikan pada model kepuasan yang digunakan ketika mengevaluasi faktorfaktor yang mempengaruhi kepuasan pengguna akhir.

Model end user computing satisfaction banyak digunakan dalam menguji faktor-faktor yang mempengaruhi kepuasan pengguna akhir. Pikkarainen et al melakukan penelitian pada layanan online-banking di Finlandia, hasilnya menyatakan bahwa tiga variabel dari model Doll dan Torzakdeh digunakan untuk menganalisis kepuasan pengguna online-banking[4]. Seddon beranggapan bahwa system quality berpengaruh pada user satisfaction, hal tersebut terbukti secara empiris[5]. Begitu pula hasil penelitian Istianingsih dan Wijayanto menunjukkan hasil yang sama bahwa system quality berpengaruh terhadap kepuasan pengguna[6]. Oleh karena itu pada penelitian ini akan menggunakan variabel system quality sebagai variabel eksternal dari model EUCS yang bisa digunakan untuk menjelaskan fakor-faktor penentu kepuasan pengguna akhir. Berbeda dengan hasil penelitian yang dilakukan oleh Irfan[7] yang menunjukkan bahwa system quality yang ditambahkan pada model EUCS tidak memberikan pengaruh signifikan kepada kepuasan pengguna sistem akademik di Universitas Batanghari. Tujuan penelitian ini sekaligus ingin membuktikan secara empiris pengaruh variabel kualitas sistem yang banyak digunakan oleh penelitian sebelumnya sebagai variabel eksogen eksternal yang memberikan pengaruh kepada kepuasan pengguna akhir sebuah SI, namun digunakan untuk menyelesaikan permasalahan tingkat faktor kepuasan pengguna SI akademik di Politeknik Negeri Balikpapan.

Berdasarkan hasil dari evaluasi model struktural menggunakan PLS, R-Square merepresentasikan jumlah variance dari konstruk yang dijelaskan model. Pada Tabel 1 dapat dilihat bahwa nilai $R$-square variabel user satisfaction yaitu sebesar 0,653 sehingga dapat disimpulkan variabel user satisfaction dapat dijelaskan oleh variabel independen dalam model penelitian ini sebesar $65,3 \%$, yaitu accuracy, format, ease of use dan timeliness.

Tabel 1. Nilai R-Square

\begin{tabular}{cc}
\hline Variabel & R-square \\
\hline User Satisfaction & 0,653 \\
\hline
\end{tabular}

Sedangkan sisanya dijelaskan oleh variabel lain diluar model penelitian ini sebesar 34,7\%. Hal ini yang menjadi permasalahan utama yang ingin diselesaikan dalam penelitian kali ini, permasalahan yang serupa juga terjadi pada penelitian sebelumnya[3] oleh karena itu penting mencari variabel eksternal yang teruji secara empiris memiliki pengaruh yang bisa dijadikan dasar penambahan variabel eksogen pendukung didalam model EUCS. Tujuan dari penelitian ini adalah untuk menguji hubungan antara variabel kualitas sistem Delone and Mclane [8] dengan variable yang terdapat pada EUCS[9]. maka hipotesis penelitian dari integrasi kedua model tersebut dapat ditunjukkan pada Gambar 1.

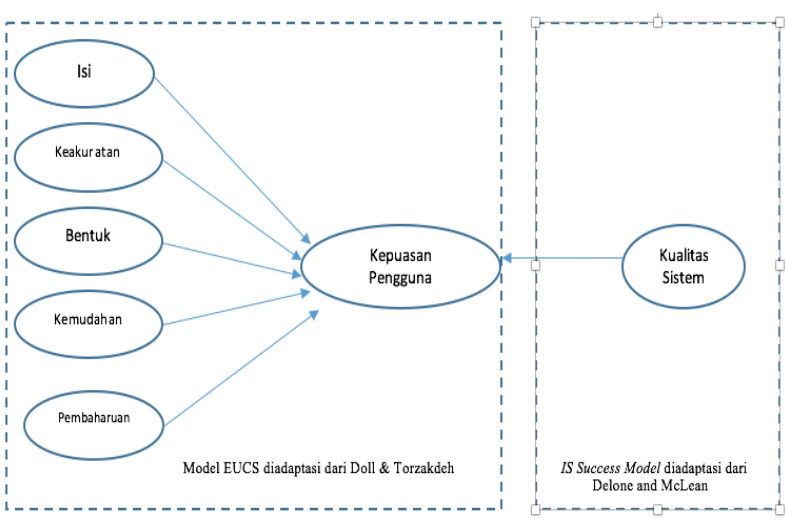

Gambar 1. Model Hipotesis Penelitian

Seperti yang ditunjukkan pada Gambar 1. maka penelitian ini akan fokus kepada pengujian maupun pembuktikan pengaruh variabel kualitas sistem terhadap kepuasan pengguna. Hasil pengujian ini nantinya bisa digunakan dalam melakukan pengembangan sebuah SI dengan mengadopsi variabel lain yang relevan dan memiliki signifikansi terhadap model EUCS. Delone[10]menyatakan bahwa kepuasan pengguna adalah komponen penting dalam keberhasilan sistem informasi. Hal ini banyak membuat penelitian tentang kepuasan pengguna sebagai topik riset sistem informasi. 
Penelitian sebelumnya yang dilakukan oleh Seddon ini. Loading factor dan average variance extracted memodifikasi model yang dibuat oleh DeLone dan (AVE) adalah nilai yang akan digunakan untuk menguji McLean dengan membuat satu model untuk mengukur validitas dari pertanyaan penelitian yang dapat dilihat kepuasan pengguna sistem informasi yang terdiri dari dari cross loadings. Loading factor adalah nilai uji kualitas sistem (system quality), kualitas informasi validitas konvergen untuk tiap indikator pertanyaan, (information quality), persepsi kegunaan (perceived dengan prinsip bahwa pengukur-pengukur dari suatu usefulness), kepuasan pengguna (user satisfaction), konstruk seharusnya berkorelasi tinggi[15], seperti manfaat untuk individu (individuals), dan organisasi yang ditunjukkan pada Tabel 2.

(organization) serta manfaat untuk masyarakat (society)[10],[11]. Budiarta menunjukkan bahwa variasi variabel kepuasan pengguna akhir software akuntansi Tabel 2. Rule of Thumb Validitas Konvergen

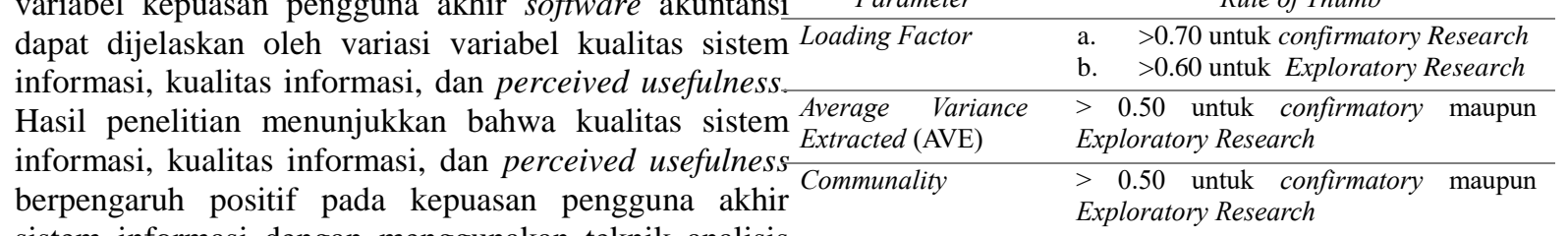
sistem informasi dengan menggunakan teknik analisis linier berganda. Hasil penelitian ini berarti semakin baik kualitas sistem informasi, kualitas informasi, dan 2.2 Uji Reliabilitas

perceived usefulness maka akan meningkatkan kepuasan Langkah kedua melakukan uji reliabilitas dilakukan pengguna akhir software akuntansi[12]. Sebuah dengan melihat nilai cronbachs alpha dan composite penelitian pernah dilakukan untuk menguji secara reliability, dimana nilai cronbachs alpha harus lebih empiris arah pengaruh kualitas sistem informasi dengan besar dari 0,6 atau dapat dilihat pada Tabel 3 . metode kuesioner dan wawancara, teknik pengambilan Tujuannya adalah untuk membuktikan akurasi, sampling dilakukan dengan metode purposive sampling. konsistensi dan ketepatan instrumen dalam mengukur Hasil penelitian menunjukkan bahwa kualitas sistem variabel.

informasi berpengaruh positif terhadap kepuasan pengguna akhir sistem informasi[13]. Sedangkan Irfan

Tabel 3. Rule of Thumb Uji Reabilitas melakukan penelitian untuk mengevaluasi faktor-faktor Parameter Rule of Thumb yang mempengaruhi kepuasan pengguna akhir sistem Cronbach's Alpha a. $>0.70$ untuk confirmatory Research informasi akademik dengan menggabungkan antara b. $>0.60$ masih dapat diterima untuk model end user satisfaction dan variabel kualitas sistem informasi Delone and Mclean. Hasil dari penelitian ini Reliability menunjukkan bahwa kualitas sistem tidak memberikan Exploratory Research

a. $>0.70$ untuk Confirmatory Research

b. $\quad 0.60-0.70$ masih dapat diterima untuk pengaruh secara signifikan terhadap kepuasan pengguna[7]. Penelitian yang dilakukan Vassilios et 2.3 Analisis Model Struktural

al[14] menunjukkan bahwa instrumen end user Langkah berikutnya adalah melakukan analisis model satisfaction dapat digunakan untuk mengevaluasi sistem struktural atau yang sering disebut dengan Inner Model. informasi rumah sakit. Instrumen tidak hanya Inner model dievaluasi dengan menggunakan $R$-Square menyediakan keseluruhan penilaian kepuasan pengguna untuk variabel dependen dan uji $\mathrm{t}$ dengan tingkat akhir tetapi juga kemampuan untuk mengidentifikasi signifikansi sebesar 0.05 ( $t$-statistic $>t$-table) dari aspek yang paling bermasalah dari upaya implementasi koefisien parameter jalur struktural. Perubahan nilai $R$ Hospital Information System (HIS). Selain itu square dapat digunakan untuk menilai pengaruh dibuktikan bahwa kualitas sistem secara positif variabel laten independen tertentu terhadap variabel mempengaruhi kepuasan pengguna akhir. Hasil laten dependen yang dapat digunakan untuk penelitian juga memberikan kesimpulan bahwa semua mengetahui pengaruh yang substantif. Nilai $R$-Square instrumen penelitian yang menjadi indikator user akan muncul pada variabel laten endogen (dependen) satisfaction yang dibangun oleh Doll dan Torkzadeh [9] yang dipengaruhi oleh variabel laten eksogen memiliki validitas dan reliabilitas yang sangat baik.

\section{Metode Penelitian}

\subsection{Uji Validitas}

Metode yang digunakan dalam penelitian ini adalah dengan melakukan analisis model struktural atau inner model. Langkah awal adalah melakukan uji validitas $\begin{array}{llll}\text { model. Langkah awal adalah melakukan uji validitas } & \text { Signifikansi } \\ \text { untuk menguji validitas pernyataan-pernyataan } & \text { (two-tailed) }\end{array}$ kuesioner yang digunakan sebagai alat dalam penelitian (independen). Semakin tinggi nilai dari $R$-Squares, berarti semakin baik model penelitian[15]. Nilai minimal yang dijadikan acuan untuk uji model struktural dapat dilihat pada Tabel 4.

Tabel 4. Rule of Thumb Model Struktural 
Dalam penelitian ini menggunakan 5 (lima) variabel indikator pertanyaan dengan variabel laten sudah valid yang terdapat dalam model EUCS yaitu content, dan layak digunakan dalam penelitian ini. accuracy, format, ease of use dan timeliness. Selanjutnya ditambah 1 (satu) variabel kualitas sistem dari model information success model yang diintegrasikan untuk mengukur atau mengevaluasi faktor-faktor yang mempengaruhi kepuasan pengguna sistem informasi. Keseluruh variabel penelitian tersebut disusun kedalam pertanyaan kuesioner dan disebarkan ke responden pengguna sistem informasi. Pada tabel 5 dibawah ini akan menjelaskan hubungan antara variabel penelitian kualitas sistem dengan indikatornya.

Tabel 5. Instrumen Penelitian Kualitas Sistem

\begin{tabular}{|c|c|c|c|}
\hline Variabel & Kode & Indikator & Pertanyaan \\
\hline \multirow{3}{*}{$\begin{array}{l}\text { Kualitas } \\
\text { Sistem }\end{array}$} & SQ1 & $\begin{array}{l}\text { Fleksibilitas } \\
\text { respone } \\
\text { time }\end{array}$ & $\begin{array}{l}\text { Ketika saya mengakses } \\
\text { SI selalu memiliki } \\
\text { response time yang } \\
\text { optimal meskipun } \\
\text { diakses dari luar } \\
\text { lingkungan kampus }\end{array}$ \\
\hline & SQ2 & Intuisi & $\begin{array}{l}\text { SI memiliki password } \\
\text { bagi masing-masing } \\
\text { pengguna, sehingga } \\
\text { pengguna yang tidak } \\
\text { berhak tidak dapat } \\
\text { mengakses data yang } \\
\text { ada didalamnya }\end{array}$ \\
\hline & SQ3 & $\begin{array}{l}\text { Keandalan } \\
\text { sistem }\end{array}$ & $\begin{array}{l}\text { SI selalu memberikan } \\
\text { informasi yang saya } \\
\text { butuhkan kapan saja } \\
\text { tanpa } \\
\text { kendala/masalah }\end{array}$ \\
\hline
\end{tabular}

Variabel laten system quality terdiri dari 3 indikator, yaitu system quality 1 , system quality 2 dan system quality 3. SQ 1 memiliki nilai loading sebesar 0.824 dan $S Q 2$ memiliki nilai loading sebesar 0.781 dan SQ 3 memiliki nilai loading 0.700 dapat dilihat pada Tabel 7. Maka variabel system quality telah memenuhi syarat convergent validity.

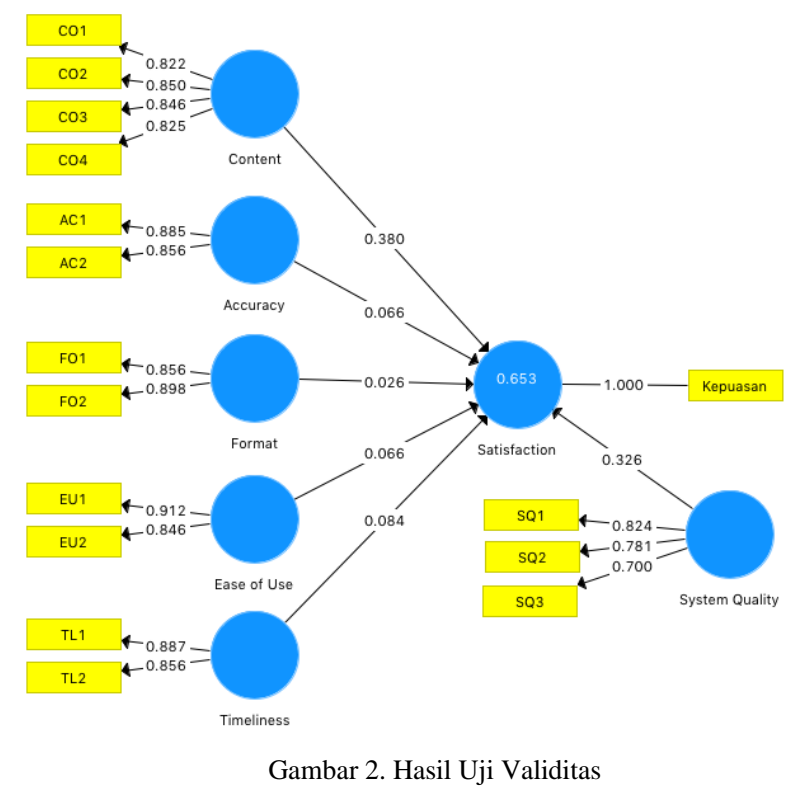

Hipotesis yang dibuat dalam penelitian ini akan diuji dengan menggunakan $R$-Square untuk variabel dependen dan uji t dengan tingkat signifikansi sebesar 0.05 ( $t$-statistic $>t$-table) dari koefisien parameter jalur struktural. Hasil uji hipotesis ini dapat dilihat pada Gambar 4.

\section{Hasil dan Pembahasan}

Tabel 7. Nilai Loading untuk Variabel Laten System Quality

\begin{tabular}{lll}
\hline \multicolumn{1}{c}{ Indikator } & \multicolumn{3}{c}{ Pertanyaan } & $\begin{array}{c}\text { Nilai } \\
\text { Loading }\end{array}$ \\
\hline System quality 1 & $\begin{array}{l}\text { Ketika saya mengakses SI } \\
\text { selalu memiliki response time }\end{array}$ & 0.824 \\
& $\begin{array}{l}\text { yang optimal meskipun } \\
\text { diakses dari luar lingkungan } \\
\text { kampus }\end{array}$ \\
\hline System quality 2 & $\begin{array}{l}\text { SI memiliki password bagi } \\
\text { masing-masing pengguna, }\end{array}$ \\
& $\begin{array}{l}\text { sehingga pengguna yang tidak } \\
\text { berhak tidak dapat mengakses }\end{array}$ \\
& data yang ada didalamnya & \\
\hline System quality 3 & $\begin{array}{l}\text { SI selalu memberikan } \\
\text { informasi yang saya butuhkan }\end{array}$ \\
& $\begin{array}{l}\text { kapan saja tanpa adanya } \\
\text { kendala/masalah }\end{array}$ \\
\hline
\end{tabular}

3.1 Uji Validitas dan Reliabilitas untuk Menguji Kuesioner sebelum Penelitian

Uji validitas instrumen dilakukan untuk mengetahui kesesuaian dan kecukupan pertanyaan yang diajukan dalam kuesioner untuk menjadi dasar bagi penelitian. Validitas dilakukan pada masing -masing variabel laten yang ada. Gambar 2 merupakan hasil uji validitas data Kemudian dari hasil uji reliabilitas untuk membuktikan yang dilakukan dengan menggunakan program akurasi, konsistensi dan ketepatan instrumen dalam SmartPLS versi 3.0. Hubungan antara variabel dengan mengukur konstruk. Untuk mengukur suatu konstruk indikator pertanyaan memiliki nilai loading yang tidak dengan indikator refleksif dapat dilakukan dengan sama, dapat dilihat bahwa nilai loading berada 0,60 cronbach's alpha dan composite reliability seperti menandakan hubungan yang sesuai antara variabel ditunjukkan pada Tabel 8. Hasil yang didapatkan laten dengan indikator pertanyaan dari variabel menunjukkan bahwa variabel-variabel yang digunakan tersebut, sedangkan nilai loading dibawah 0,60 untuk pengukur kepuasan, termasuk kualitas sistem menandakan hubungan yang tidak sesuai antara yang berasal dari model eksternal yang digabungkan variabel dengan indikator lainnya. Sehingga dapat kedalam model penelitian yang digunakan sudah disimpulkan berdasarkan hasil uji validitas bahwa reliable atau handal. Hal ini ditunjukkan dengan nilai Cronbach alpha system quality diatas 0,50. Sedangkan 
system quality memiliki nilai cronbach's alpha sebesar dibandingkan dengan hasil penelitian sebelumnya 0,669 dan composite reliability sebesar 0,813 yang dengan menggunakan model dan metode yang sama menandakan bahwa system quality memiliki instrumen membuktikan bahwa 4 dari 5 variabel model memiliki yang akurat, konsisten dan tepat.

Tabel 8. Nilai Cronbachs Alpha dan Composite Reliability

\begin{tabular}{lll}
\hline Variabel & Cronbachs Alpha & $\begin{array}{l}\text { Composite } \\
\text { Reliability }\end{array}$ \\
\hline Accuracy & 0.682 & 0.862 \\
\hline Content & 0.856 & 0.903 \\
\hline Ease of Use & 0.712 & 0.872 \\
\hline Format & 0.702 & 0.870 \\
\hline Timeliness & 0.685 & 0.864 \\
\hline Satisfaction & 1.000 & 1.000 \\
\hline System Quality & 0.669 & 0.813 \\
\hline
\end{tabular}

3.2. Analisis Tingkat Kepuasan Pengguna Sistem Informasi Berdasarkan Variabel Kualitas Sistem

Pada Gambar 3. menunjukkan bahwa dari ketiga indikator yang digunakan untuk mengukur kualitas sistem (system quality) pada SI, mayoritas responden menjawab setuju. Pengumpulan data kuesioner menggunakan model skala likert antara lain : sangat tidak setuju (STS), tidak setuju (TS), netral (N), setuju (S) dan sangat setuju (SS). Variabel system quality merupakan ukuran kualitas pemrosesan informasi pada SI, hal ini sekaligus merujuk pada peforma dari sistem. Seberapa baik kemampuan perangkat keras, perangkat lunak, kebijakan dan sekaligus prosedur dari sistem dapat menyediakan informasi kebutuhan pengguna.

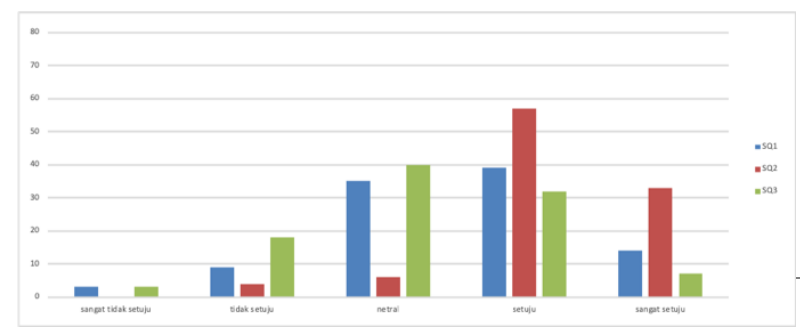

Gambar 3. Grafik Jawaban Reponden untuk Variabel Quality System

Berdasarkan Gambar 3. terlihat bahwa mayoritas $\mathrm{H} 1$ responden yakni sebesar $42.7 \%$ dari total jumlah responden menjawab setuju atas pernyataan mengenai kualitas (system quality) sistem. Kemudian responden $\mathrm{H}$ yang menjawab sangat setuju sebesar $42.7 \%$, netralsebesar $27 \%$, tidak setuju $10.3 \%$ dan responden yang menjawab sangat tidak setuju sebesar $2 \%$.

\subsection{Hasil Pengujian Model Struktural}

Pada Gambar 3. menampilkan secara visual hasil dari pengaruh kepada kepuasan pengguna SIAO.

pengolahan model struktural atau inner model yang dilakukan menggunakan teknik structural equation model dengan tool Smart Pls 3.0 untuk menguji arah hubungan antara variabel kualitas sistem dengan kepuasan pengguna. Hasil yang didapatkan adalah dari 6 variabel hanya 2 variabel yang memberikan pengaruh secara signifikan terhadap kepuasan pengguna. Jika pengaruh terhadap kepuasan[16]. Berdasarkan Gambar 3. $R$-Square yang dihasilkan dalam penelitian ini sebesar 0.653 jika dijadikan persen sebesar $65.3 \%$, dimana nilai $r$-square yang mendekati satu memberikan persentase pengaruh yang besar.

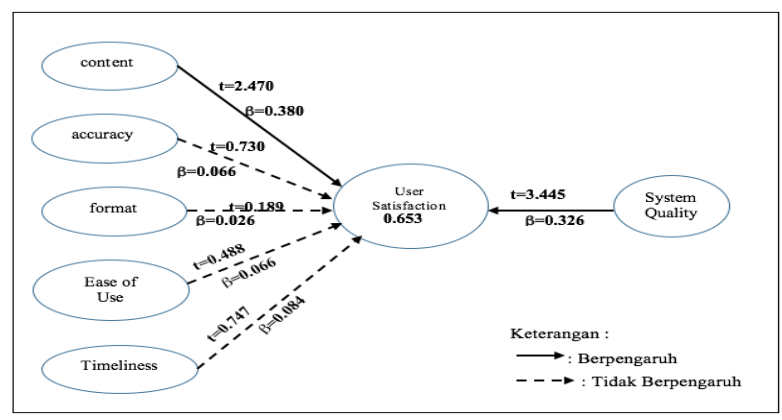

Gambar 4. Model Struktural Hipotesis

Gambar 4. menampilkan keseluruhan model struktural yang terdiri hipotesis, nilai path coefficients $(\beta)$, $t$ statistics dan r-square. Tampilan visual ini memudahkan dalam menilai signifikansi dari path coefficient. Pada Gambar 3. terlihat bahwa system quality berpengaruh langsung terhadap user satisfaction. Pengujian hipotesis dilakukan melalui prosedur bootstrapping pada program SmartPLS 3.0. Tingkat signifikansi yang digunakan adalah 95\% $(\alpha=0,05)$ dengan $T$-table sebesar 1,96. Apabila nilai $T$ statistic lebih kecil dari 1,96, maka hipotesis akan ditolak. Tabel 6 menunjukkan hasil path coefficients dan $T$-value pada inner model.

Tabel 6. Kesimpulan Hipotesis Penelitian

\begin{tabular}{llll}
\hline Hipotesis & Arah Pengaruh & Hasil \\
\cline { 2 - 3 } & Dari & Ke & \\
\hline H1 & content & User satisfaction & Diterima \\
\hline H2 & Accuracy & User satisfaction & Ditolak \\
\hline H3 & Format & User satisfaction & Ditolak \\
\hline H4 & Ease of Use & User satisfaction & Ditolak \\
\hline H5 & Timeliness & User satisfaction & Ditolak \\
\hline H6 & System Quality & User satisfaction & Diterima \\
\hline
\end{tabular}

Berdasarkan hasil pengujian Tabel 6, diperoleh hasil pengujian khusus variable eksternal kualitas sistem Delone and Mclane sebagai berikut :

H6 : Kualitas (system quality) sistem memberi Hasil pengujian hipotesis menunjukkan besar pengaruh variabel system quality mempengaruhi atau dengan kata lain terdapat pengaruh positif terhadap variabel user satisfaction sebesar 0,326, dengan nilai t-statistics sebesar 3,445. Jika nilai t-statistics dibandingkan dengan nilai $T$-table pada signifikansi $\boldsymbol{\alpha}=\mathbf{0 , 0 5}(\mathbf{5 \%})$ yaitu 1,96 , maka nilai tersebut lebih besar sehingga 
variabel system quality dinyatakan berpengaruh secara signifikan terhadap variabel user satisfaction ( $t$ statistics $=3,445>t$-table $=1,96)$.

Model Doll dan Torkzadeh menyatakan sebelumnya bahwa 5(lima) faktor dalam modelnya mampu memberi kontribusi terhadap kepuasan pengguna, sedangkan dalam penelitian ini hanya faktor isi informasi (content) yang berpengaruh terhadap kepuasan pengguna. Adapun variabel yang memberi pengaruh kepada kepuasan pengguna berasal dari variabel diluar model ini yaitu variabel kualitas sistem yang dikembangkan oleh Delone dan Mclean. Dari hasil uji hipotesis yang dilakukan bisa diketahui terdapat hubungan antara variabel kualitas sistem yang bisa memberikan pengaruh secara signifikan terhadap kepuasan pengguna dalam model penelitian ini.

Hasil penelitian ini mendukung penelitian yang dilakukan oleh chung[17]dalam meneliti pengaruh tingkat kepercayaan kepuasan mobile banking, dimana kualitas sistem berpengaruh secara positif terhadap kepuasan konsumen. Begitu pula dengan penelitianpenelitian serupa yang menguji arah pengaruh kualitas sistem terhadap kepuasan pengguna yang menunjukkan pengaruh positif[18],[19],[20]. Sehingga dari hasil penelitian ini bisa lebih memperkuat dan memperdalam pembuktian pengaruh variabel kualitas sistem sebagai variabel eksogen eksternal yang telah teruji empiris ketika digunakan pada model EUCS.

\section{Kesimpulan}

Variabel kualitas sistem yang berasal dari variabel diluar model ini yang dikembangkan oleh Delone dan Mclean memberi pengaruh kepada kepuasan pengguna. Berdasarakan hasil pengujian hipotesis menunjukkan besar pengaruh variabel system quality mempengaruhi atau dengan kata lain terdapat pengaruh positif terhadap variabel user satisfaction sebesar 0,326, dengan nilai $t$ statistics sebesar 3,445. Jika nilai t-statistics dibandingkan dengan nilai $T$-table pada signifikansi $\boldsymbol{\alpha}=\mathbf{0 , 0 5}(\mathbf{5 \%})$ yaitu 1,96 , maka nilai tersebut lebih besar sehingga variabel system quality dinyatakan berpengaruh secara signifikan terhadap variabel user satisfaction $(t$-statistics $=3,445>t$-table $=1,96)$.

\section{Ucapan Terimakasih}

Terima kasih kepada Politeknik Negeri Balikpapan yang telah mendanai penelitian ini melalui DIPA Poltekba Tahun Anggaran 2018. Sehingga penelitian ini berjalan dengan lancar dan semoga bermanfaat dalam pengembangan bidang ilmu sistem informasi.

\section{Daftar Rujukan}

[1] H.Jogiyanto, Sistem Teknologi Informasi. 2005

[2] W. W. Chin and M. K. O. Lee, "On The Formation of End-
User Computing Satisfaction: A Proposed Model And Measurement Instrument," pp. 1-16.

[3] N. K. Lankton and E. V. Wilson, "Factors Influencing Expectations of e-Health Services within a Direct-Effects Model of User Satisfaction," e-Service J., vol. 5, no. 2, pp. 85112, 2007.

[4] K. Pikkarainen, T. Pikkarainen, H. Karjaluoto, and S. Pahnila, "The measurement of end-user computing satisfaction of online banking services: empirical evidence from Finland," Int. J. Bank Mark, vol. 24, no. 3, pp. 158-172, 2006.

[5] P. Seddon and M.-Y. Kiew, "A Partial Test and Development of Delone and Mclean's Model of IS Success," Australas. J. Inf. Syst., vol. 4, no. 1, pp. 90-109, 1996.

[6] S. H. W. Istianingsih, "Pengaruh Kualitas Sistem Informasi, Perceived Usefulness, dan Kualitas Informasi Terhadap Kepuasan Pengguna Akhir Software Akuntansi," Universitas Indonesia, 2008.

[7] A. Irfan, "Evaluasi Kepuasan Pengguna Sistem Informasi Akademik Universitas Batanghari," Universitas Gadjah Mada, 2015.

[8] W. DeLone and E. McLean, "The DeLone and McLean Model of Information Systems Success," J. Manag. Inf. Syst., vol. 19, no. 4, pp. 9-30, 2003.

[9] B. W. J. Doll, "The Measurement of End-User Computing Satisfaction The End-User Computing," no. 1983, pp. 259$275,1988$.

[10] S. Petter, W. DeLone, and E. R. McLean, "Information Systems Success: The Quest for the Independent Variables," J. Manag. Inf. Syst., vol. 29, no. 4, pp. 7-62, 2013.

[11] P. B. Seddon, "A Respecification and Extension of the DeLone and McLean Model of IS Success," Information Systems Research, vol. 8, no. 3. pp. 240-253, 1997.

[12] N. M. S. R. Budiartha, I Ketut, "Pengaruh Kualitas Sistem Informasi, Kualitas Informasi Dan Perceived Usefulness Pada Kepuasan Pengguna Akhir Software Akuntansi (Studi Empiris Pada Hotel Berbintang Di Provinsi Bali)," E-Jurnal Ekon. dan Bisnis Univ. Udayana 5.1, vol. 1, pp. 115-142, 2016.

[13] Wi. Septianita, W. Agus Winarno, and A. Arif, "Pengaruh Kualitas Sistem , Kualitas Informasi, Kualitas Pelayanan Rail Ticketing System ( RTS ) Terhadap Kepuasan Pengguna ( Studi Empiris Pada PT . KERETA API INDONESIA ( PERSERO ) DAOP 9 JEMBER )," e-Journal Ekon. Bisnis dan Akutansi, vol. 1, no. 1, pp. 53-56, 2014.

[14] V. P. Aggelidis and P. D. Chatzoglou, "Hospital information systems: Measuring end user computing satisfaction (EUCS)," J. Biomed. Inform., vol. 45, no. 3, pp. 566-579, 2012.

[15] I. Ghozali and H. Latan, Partial Least Squares Konsep, Teknik dan Aplikasi Menggunakan Program Smart PLS 3.0 untuk Penelitian Empiris, 2nd ed. Semarang: Universitas Diponegoro Semarang, 2014.

[16] B. Suzanto and I. Sidharta, "Pengukuran End-User Computing Satisfaction Atas Penggunaan Sistem Informasi Akademik," $J$. Ekon. Bisnis Entrep., vol. 9, no. 1, pp. 16-28, 2015.

[17] N. Chung and S. J. Kwon, "Effect of trust level on mobile banking satisfaction: A multi-group analysis of information system success instruments," Behav. Inf. Technol., vol. 28, no. 6, pp. 549-562, 2009.

[18] C. L. Hsu, K. C. Chang, and M. C. Chen, "The impact of website quality on customer satisfaction and purchase intention: Perceived playfulness and perceived flow as mediators," Inf. Syst. E-bus. Manag., vol. 10, no. 4, pp. 549$570,2012$.

[19] M. Karlinsky-Shichor, Yael; Zviran, "Factors Influencing Perceived Benefits and User Satisfaction in Knowledge Management Systems," Inf. Syst. Manag., vol. 33, no. 1, pp. 55-73, 2016.

[20] J. Luo, S. Ba, and H. Zhang, "The Effectiveness of online shopping characteristics and well-designed websites on satisfaction," MIS Q., vol. 36, no. 4, pp. 1131-1144, 2012. 